\title{
Biophysical disturbances of elephant safaris in the Royal Chitwan National Park, Nepal
}

\author{
Bodh Raj Subedi ${ }^{1}$
}

\begin{abstract}
The paper explores peoples' perceptions on the biophysical impacts of elephant safaris which is a perfect way to go wildlife viewing, and is very eco-friendly. It surpasses its alternatives, especially noisy Jeep safaris. However, more people are becoming aware of the biophysical impacts of the safaris in the park. They perceived that the safaris cause negative impacts on wildlife and can destroy habitat through soil compaction and erosion, vegetation damage and disturbances. The study also estimated that the current wildlife observation distance from elephant safaris are less than fifteen metres which is too close and may be harmful to wildlife. This study provides interesting comparisons with previous studies on impacts of tourist activities on wildlife from a biological perspective in that the appropriate distances perceived by park staff to view wildlife was the only one to "fit" their findings. The distances perceived by other groups of people as appropriate would in fact, cause unacceptable levels of disturbance. It is concluded that social (human) perception of disturbance by elephant safaris may not accurately reflect the biological severity of their impacts.
\end{abstract}

Key words: Wildlife, eco-tourism, recreation, elephant safaris, Royal Chitwan National Park, biophysical impacts, Nepal

$T^{1}$ he Royal Chitwan National Park (RCNP) is renowned for its large variety of wildlife, including rhinoceros and tiger. These animals can be viewed during safaris from the back of an elephant.

Elephant safari is one of the most popular activities related to park tourism. The RCNP is operating its own elephants for tourism and seven other concessionaire hotels have been guaranteed licenses to operate elephant safaris in different areas of the park.

Elephant safaris are presently concentrated in critical habitats and localities. For instance, they are highly intensified in the Icharni Tapu of the Sauraha (the main entrance of the park), and more than twenty elephant safaris meet the rhino-population residing at this area. Such safari trips are quite often organised two to four times a day particularly in the morning and in the evening during the peak tourist season. According to the Department of National Parks and Wildlife Conservation (DNPWC), there is also an increasing demand by other private parties to operate more elephant safaris inside the park, questioning the natural balance of its ecosystem.

There is no doubt that elephant safaris in the park have provided employment and income opportunities for tourist operators and local communities. In addition, the safaris generated second highest amount of revenue (more than $16 \%$ ) after the entry fee (about 65 $\%$ ) of the total revenue (over NRs. 48.29 million) for the park in the fiscal year 1996/97 (Subedi, 1999). But one must also not forget of its consequences. In this connection, the present paper investigates the perceived vegetation damage and wildlife disturbances of elephant safaris and suggests practical management recommendations to enhance the quality of elephant safaris while minimising impacts in the park.

\section{Methods}

Both qualitative and quantitative approaches were adapted for this study. Two different questionnaires were developed. A self-administered questionnaire was offered to park visitors (203) and the other set was used for interviewing Mahut (elephant drivers- $N=40$ ), tourist guides (30), and park staff (30) on quota basis. An error margin of the results derived from this visitor survey (quota sampling) is plus or minus 6.9 percent. More than ten key informants, including park managers and conservationists were interviewed. Field observations to gain an in depth knowledge of the wildlife responses to the elephant safaris were also done.

\section{Results and discussion}

The demand for elephant safaris has risen as a result of increasing tourist visits to the park. The total 


\section{Subedi}

number of tourists visiting the park increased from 836 in $1973 / 74$ to 105,880 in $1998 / 99$ (Table 1). With an average annual growth rate of 30.9 percent (Subedi, 1999), this rate of growing tourism in the park has topped the national trend of 13 percent (Banskota, et al.y 1996). Such trend of visitors inevitably produces pressure in the park and is contributing to both ecosystem degradation and reduction of the quality of the touristic experience.

The present study has revealed that an elephant safari is a perfect way to go wildlife viewing and more than 97 percent of visitors coming to RCNP took part in it. It is eco-friendly, and surpasses its alternatives, especially noisy vehicle safaris. However, more people are becoming aware of the biophysical impacts of the safaris in the park. They perceive that the safaris cause negative impacts on wildlife and can ultimately provide a negative impact on their habitat through litter, soil compaction and erosion, vegetation damage and wildlife disturbance, etc. Problems with litter and pollution, soil compaction and soil erosion are infrequently reported and there is an overall agreement that there is no significant problem of litter or pollution from elephant safaris in the park.

The hypothesis "elephant safaris damage vegetation" and "elpehant safaris cause wildlife disturbances" are adapted to judge the perceived impacts of local respondents. Information obtained from visitor surveys, from field observations and from interviews with key informants were also included to supplement these statements and to illustrate the nature of the perceived impacts.

The above statement received the mean score of 3.76 with a standard deviation of 1.2 which indicated that there was an overall agreement with the statement. The chi-square test shows that there was no significant difference in the opinions among the sub groups of the respondents $\left\{\%^{2}(2,83)=0.37\right.$, n.s. $\}$. However, above figure shows that the majority of the park staff $(73 \%)$ and tourist guides $(76 \%)$ strongly perceived that elephant safaris damage vegetation. Such damage arises partly as a result of direct impacts such as grazing of elephants, lopping and breaking branches and removing trees, or disturbance of soil on elephant trails. Species such as
Banko Janakari, Vol. 9, No. 2

Simal (Bombax cieba), Khair (Acacia catechue) and many figs and other palatable species are suspected to decrease, which may affect the park fauna. However, the Mahuts perceived less impact from elephant safaris on vegetation than either the park staff or tourist guides. This may be due to their lower degree of awareness on the ecological consequences of vegetation damage by their elephants.

\begin{tabular}{|c|c|c|}
\hline $\begin{array}{l}\text { Fiscal } \\
\text { Years }\end{array}$ & Number of visitors & \% growth \\
\hline $1973 / 74$ & 836 & \\
\hline $1974 / 75$ & 2,206 & 163.9 \\
\hline $1975 / 76$ & 5,021 & 127.6 \\
\hline $1976 / 77$ & 5,547 & 10.5 \\
\hline $1977 / 78$ & 8,325 & 50.1 \\
\hline $1978 / 79$ & 6,250 & -24.9 \\
\hline $1979 / 80$ & 12,503 & 100.0 \\
\hline $1980 / 81$ & 11,218 & -10.3 \\
\hline $1981 / 82$ & 11,602 & 3.4 \\
\hline $1982 / 83$ & 11,714 & 1.0 \\
\hline $1983 / 84$ & 14,606 & 24.7 \\
\hline $1984 / 85$ & 14,156 & -3.1 \\
\hline $1985 / 86$ & 25,490 & 80.1 \\
\hline $1986 / 87$ & 38,565 & 51.3 \\
\hline $1987 / 88$ & 44,890 & 16.4 \\
\hline $1988 / 89$ & 36,275 & -19.2 \\
\hline $1989 / 90$ & 43,750 & 20.6 \\
\hline $1990 / 91$ & 55,335 & 26.5 \\
\hline $1991 / 92$ & 55,442 & 0.2 \\
\hline $1992 / 93$ & 58,998 & 6.4 \\
\hline $1993 / 94$ & 64,749 & 9.8 \\
\hline $1994 / 95$ & 83,898 & 29.6 \\
\hline $1996 / 97$ & 96,062 & 14.5 \\
\hline $1997 / 98$ & 104,046 & 8.3 \\
\hline 1998/99 & 105,880 & 1.8 \\
\hline
\end{tabular}

Source: RCNP,

This hypothesis statement "elephant safaris cause wildlife damage" had a mean score of 3.38 with a standard deviation of 1.32 which indicated an overall agreement that elephant safaris disturb wildlife. A chi-square test showed that there was a significant difference between responses of the three sub-groups on wildlife disturbances of elephant safaris $\{\%(4,84)=9.36), p=$ $0.05\}$.

Table 2: Responses on impact of elephant safaris on vegetation

\begin{tabular}{lllllll}
\hline Respondents & $\begin{array}{l}\text { Strongly } \\
\text { disagree }\end{array}$ & $\begin{array}{l}\text { Slightly } \\
\text { disagree }\end{array}$ & Neutral & $\begin{array}{l}\text { Slightly } \\
\text { agree }\end{array}$ & Strongly agree & Total \\
\hline Park Staff & 4 & 5 & 4 & 9 & 13 & 30 \\
Elephant Drivers & 1 & 4 & 11 & 18 & 4 & 39 \\
Tourist Guides & 2 & 9 & 1 & 9 & 14 & 30 \\
Total & 7 & 16 & 36 & 31 & 99 \\
\hline
\end{tabular}




\section{Banko Janakari, Vol. 9, No. 2}

Different opinions of the statement with 15.2 percent neutral responses were found (Table 3). Fifty three percent of the park staff and 73 percent tourist guides perceived that elephant safaris cause wildlife disturbances. By contrast, more than two- third of park visitors and 41 percent of Mahuts did not perceive any wildlife disturbance. However, information collected during this research and previous researches (Lott and McCoy, 1995; Cosgriff, 1997) suggested that the behaviour of some wildlife such as rhinoceros and sambar in the area where elephant safaris were high, has some what changed than their relatives of other areas. They have less reactive to elephant safaris due to the frequent contact for the last ten to fifteen years (Subedi and Devlin, 1998).

The numbers of sightings of individual animals and the number of species in the Sauraha area have declined. Elephant safaris have to spend more time to search for rhinos, and sometimes they have to travel far to view other wildlife. Species such as tiger, leopard, sloth bear, spotted deer and bison have moved away from the Sauraha area to other
Subedi

unlikely to be accepted and finally, the baby will die or killed by predators.

Studies have indcated that the feeding time of different large animals of the park is in the early mornings and late afternoons (Laurie, 1978; Mishra, 1982; Dungel and Ogara, 1991), which unfortunately, coincides with elephant safaris. And, the increased numbers of safaris have caused a greater interruption to feeding as safari elephant approaches close to the animals. This may lead to significant impacts on large herbivores because they require a considerable amount of time for feeding to remain healthy (Stockwell etal., 1991).

Similarly, the movement of elephant safaris may be more stressful for small wildlife such as hog deer and wild boar. These animals display a greater flush distance and flee more in response to elephants than they do to jeep safaris (Cosgriff, 1997). It may be argued that the sounds of the elephants' movement through the forest may be similar to predators' movements for the animals flushed.

Table 3: Responses on impact of elephant safaris on wildlife

\begin{tabular}{lllllll}
\multicolumn{2}{l}{ Table 3: Responses on impact of elephant safaris on wildife } \\
Local Respondents & $\begin{array}{l}\text { Strongly } \\
\text { disagree }\end{array}$ & $\begin{array}{l}\text { Slightly } \\
\text { disagree }\end{array}$ & \multicolumn{5}{c}{$\begin{array}{c}\text { Neutral Slightly Strongly Total } \\
\text { agree }\end{array}$} & $\begin{array}{l}\text { agree } \\
\text { Park Staff }\end{array}$ & 4 & 4 & 6 & 12 & 4 & 30 \\
Elephant Drivers & 5 & 11 & 5 & 11 & 7 & 39 \\
Tourist Guides & 3 & 1 & 4 & 11 & 11 & 30 \\
Total & 12 & 16 & 15 & 34 & 22 & 99 \\
\hline
\end{tabular}

areas. This may be due to a lack of availability of escape zones for the species. The herd size of hog deer, sambar and spotted deer has also reduced in the area.

Reported wildlife disturbances by elephant safaris include disruption of feeding, resting, wallowing, mating, grooming, and feeding babies and the disruption to bonding between the newly born baby and the mother. The rhinoceros population of the Sauraha area has frequently been disrupted from feeding and other activities. Frequent disruption of bonding between the baby and mother and interruption of feeding may have serious negative effects on the animal populations. The elephant safaris frequently disrupt the bonds between parents and offspring of the deer family and other ungulates particularly during the breeding season in the Sauraha area. The mother may flee away far from their young due to a fear of the moving elephant. As time taken to establish such bonds varies from species to species ranging from five minutes to six hours (Edington and Edington, 1986), even if the baby is physically reunited with the mother, it is
The present study also confirmed that tolerance of certain wildlife (rhinos and sambars) against elephant safaries has developed. A previous study carried out by Cosgriff (1997) estimated both "alert" and "flush" distances of some large animals including rhinos to elephant safaris. The median alert distance of rhinos to the safaris was estimated to be thirty metres in the park. The median flush distances of rhinos to the safaris were twenty five metres in the low tourist visiting (Tiger Tops) and ten metres in the high tourist visiting (Sauraha) area (Cosgriff, 1997). He concluded that rhinos and sambar have become more tolerant in high tourist areas than low tourist areas while the hog deer did not show any tolerance in either areas.

The distance between safari elephants and wildlife is an important aspect to note. Presently wildlife observation distances from elephant safaris are less than fifteen metres, which is too close and may be harmful to wildlife. A previous study carried out by Lott and McCoy (1995) also found that distances less than twelve metres disrupted rhinos' feeding and frequently displaced the animals from the feeding 


\section{Subedi}

sites they preferred. They argued that viewing distances should not be less than fifteen metres.

A considerable variation on the perception of appropriate wildlife viewing distances among the park visitors, elephant drivers, tourist guides and park staff was found. The park staff recommended this distances to be more than fifteen metres while the others suggested less than that. This indicates that the park staff are more concerned that the closeness of the safaris has negative effects on the behaviour such as the feeding and resting of wildlife. Majority of the people of the other three groups respond differently. There could be several reasons for the different perceptions of appropriate distances. The Mahuts and tourist guides have little concern about the effect of wildlife disturbances and might have been motivated to satisfy visitors. And, the latter lack knowledge of and exposure to the impact of elephant safaris during their brief visit to the park.

The present study outlined comparisons with the previous ones (e.g., Lott and McCoy, 1995; Cosgriff, 1997) related to impacts of tourist activities on wildlife from a biological perspective. The appropriate distances perceived by park staff to view wildlife were the only ones to "fit" their findings. The distances perceived by visitors, tourist guides and elephant drivers as appropriate would in fact, cause unacceptable levels of disturbance. Therefore, this study concludes that social (human) perception of disturbance by elephant safaris may not accurately reflect the biological severity of their impacts.

Considering both the studies - the social and the biological, it can be- recommended that the ideal distance to view wildlife, particularly rhinos, should not be less than fifteen metres in the high tourist visiting areas such as Sauraha, and not less than thirty metres in the low tourist visiting areas or future development areas. The populations of rhinos and sambars in the high tourist visiting areas have already become habituated and may exhibite no response to elephant safaris at the suggested distances of fifteen metre. This limit would be acceptable for both for the animals' welfare and tourists' satisfaction. However, visitation distances less than thirty metres in low tourist visiting areas would be unacceptable because the behaviour of the animals may be affected below this distance.

\section{Conclusion and recommendations}

With the growing demand for safaris by both visitors and tourist operators, and looking at its economic benefit in the one hand, while with the ecological consequences on the other, the
Banko Janakari, Vol. 9, No. 2

Department of National Parks and Wildlife Conservation has to be very cautious in making any decisions.

The viewing distances for high tourist visiting areas such as Sauraha should be fifteen metres and not closer than thirty meters for other low tourist visiting areas.

Effects of other jeep safaris and canoes including infrastructure development should be investigated.

Research should be conducted to address the question of long-term effects on wildlife disturbance and vegetation by elephant safaris in the park.

A comprehensive wildlife viewing tourism management plan should be made to enhance the quality of elephant safaris while minimising impacts in the park.

Wildlife disturbances of elephant safaris must be controlled by limiting exposure. Park wardens should limit exposure by limiting approach distances, safaris should be restricted to approach no closer than up to safe margins.

The visitors who have binoculars and telescopic cameras are content to stay at a longer distance which results in better views and less disturbances to animals. Visitors might be requested to bring such instruments. The park or tourist operators may provide binoculars for rent and slides or photographs of wildlife for sale.

The park must be zoned to elephant safaris on the basis of carrying capacity, and it should not be concentrated to a particular area, rather should be extended to different parts of the park to accommodate the demands of tourists without jeopardising the welfare of the wildlife and the vegetation involved.

The safari can be operated on a rotation basis. It is necessary that safaris are not repeated in the same areas more than once a day. The safaris may be banned in sensitive areas where the impact is very harmful (i.e. sensitive habitats of birds/ reptiles/ mammals such as nesting sites etc). A limited number of elephant safaris in the Sauraha and Tiger Tops should be allowed.

Wildlife viewing from elephant safaris may be improved by managing grassland habitats. Open patches of the size of $40 \mathrm{~m} \times 80 \mathrm{~m}$ at different sites in grassland with water holes could prove an excellent wildlife viewing sites.

Observation towers and fixed routes for the safaris could be constructed to avoid the large network of 


\section{Banko Janakari, Vol. 9, No. 2}

elephant trails particularly at Sauraha. Such tracks can minimise vegetation damage and soil compaction and erosion caused by haphazard movement of elephants.

Mahuts should be trained to collect grasses, and to adapt rotational grazing to reduce overgrazing pressure of elephants in certain areas. Lopping and cutting of trees and branches for fodder for both government and private elephants should be stopped in the park. A reliable alternative should be identified to meet the feeding requirements of the elephants. These alternatives could be through managed plantations of sugar cane and different species of in buffer zones or from prepared food.

Legal provisions related to elephant safari should be developed in consultation with stakeholders to ensure an useful and workable system.

A separate operation plan for elephant safaris, compatible with park conservation objectives is recommended. The plan should include guidelines for the operation of elephant safaris to reduce wildlife disturbances without minimising tourists' satisfaction. Issues related to the visitor safety and welfare of both wildlife and elephants, including Mahuts, must be addressed.

\section{References}

Banskota, K., Sharma, B., Sharma, U. R. and Rijal, A 1996. Royal Chitwan national park after twenty years: an assessment of values, threats and opportunities. King Mahendra Trust for Nature Conservation. Kathmandu, Nepal.

Cosgriff, K. M. 1997. Wildlife tourism in Royal Chitwan national park, Nepal: assessment of the impacts of tourist activity on large animals. Unpublished honours

\section{Subedi}

dissertation for Bachelor degree, Charles Sturt University, Albury, Australia.

Dhungal, S. K. and Ogara, B.W. 1991. Ecology of the hog deer in Royal Chitwan national park. Wildlife Monographs, 119: 1-40.

Edington, J. M. and Edington, M.A. 1986. Ecology, recreation and tourism. England: Cambridge University Press.

Laurie, A. 1978. The ecology and behaviour of the greater one-horned rhinoceros. Doctoral Thesis, University of Cambridge, England.

Lott, D. F., McCoy, M. 1995. Asian rhinos Rhinoceros unicornis on the run? impact of tourist visits on one rhino population. Biological Conservation, 73: $23-26$

Mishra, H. R. 1982. The ecology and behaviour of chital (Axis axis) in the royal Chitwan national park, Nepal. Doctoral Thesis, University of Edinburgh, UK.

Stockwell, C. A., Bateman, G. C. and Berger, J. 1991. Conflicts in national parks: a case study of helicopters and bighorn sheep time budgets in the Grand Canyon. Biological Conservation, 56: 317-328.

Subedi, B. R . 1999. Wildlife tourism and recreation: impacts of elephant safaris in the Royal Chitwan National Park, Nepal. Master Thesis, Lincoln University, New Zealand.

Subedi, B. R and Devlin, P. J. 1998. Wildlife tourism: impact of elephant safaris in Royal Chitwan National Park, Nepal. In Kandampully, J. (ed). Proceedings of the New Zealand tourism and hospitality research conference (Part 1), 1-4 December, 1998, Akaroa. New Zealand: Lincoln University. 